Economica: Journal Of Economic And Economic Education Volume 10, Issue 1, October 2021, pp 23-32

\title{
ANALYSIS OF THE EFFICIENCY OF THE MANAGEMENT OF PRIVATE HIGH SCHOOLS
}

\author{
Aditia Rhomadhani ${ }^{1)}$, Suratno ${ }^{2)}$, Kuswanto ${ }^{3)}$ \\ ${ }^{1)}$ Study Programme Economic Education, Universitas Jambi, Indonesia. \\ Email: rhomadaniaditia@gmail.com \\ ${ }^{2)}$ Study Programme Economic Education, Universitas Jambi, Indonesia. \\ Email: suratno@unja.ac.id \\ ${ }^{3)}$ Study Programme Economic Education, Universitas Jambi, Indonesia. \\ Email: kuswanto.fkip@unja.ac.id \\ Submitted: 2020.05.31 Reviewed: 2020.10.19 Accepted:2020.10.30 \\ https://doi.org/10.22202/economica.2021.v10.i1.4901
}

\begin{abstract}
The number of private high schools even makes parents reluctant to enroll their children in private high schools, due to several conditions such as the condition of facilities and infrastructure are alarming and the number of students is constantly decreasing each year. This study aims to analyze factors or inputs that affect the number of graduates of private high schools in Jambi City and measure the level of technical efficiency of private high schools in Jambi City. The results showed that the factors or inputs that influenced the number of private high school graduates in Jambi city from 2015-2019 were students and classrooms. While the factors or inputs that do not affect the number of graduates are study groups, teachers, administrative personnel, and support rooms. The technical efficiency level of 27 private high schools in Jambi city from 2015-2019, the highest in 2015 reached $0,78=78 \%$, the lowest figure occurred in 2019 only 0,27 = 27\% and the average only reached0,49=49\%, this explains that the efficiency of managing private high schools in Jambi city has not been efficient. The results of the study recommended that private high schools in Jambi city be technically efficient by optimizing the achievement of graduate competencies consisting of qualification criteria of learners' abilities that are expected to be achieved after completing their studies in the secondary education unit and the addition of classrooms is necessary to create a comfortable and disciplined learning atmosphere, orderly, anti-smoking and drugs, harmony between teachers, students and parents and maintain optimal conditions in the learning process.
\end{abstract}

Jel Classification:

F49; C67; C67.

Keywords: Technical Efficiency, School Input, School Output 


\section{INTRODUCTION}

Education is one of the instruments in shaping quality human resources. The educational unit that plays an important role in improving the quality of human resources is formal education. High School is part of the education unit of formal education providers. High School is divided into two, namely public high school and private high school. The management of public high schools is currently implemented by the Local Government. Based on the Directorate of High School Development of the Ministry of Education and Culture (Menteri Pendidikan dan Keb, 2017) in line with the reform era in which regional autonomy occurred, management was carried out by the Central and Regional Governments following their authority. Based on Government Regulation of the Republic of Indonesia Number 28 of 1981 concerning The Provision of Assistance to Private Schools in article 1 mentioned that private schools are schools established and organized by people or private entities of charitable nature.

Based on the Law of the Republic of Indonesia Number 20 of 2003 concerning the National Education System in article 51 paragraph 1 mentioned that the management of secondary education units is carried out based on minimum service standards with schoolbased management principles. To optimize the management of secondary education units, quality education management is required (Marzuki, 2012). Based on the Directorate of High School Development of the Ministry of Education and Culture (Direktorat Pembinaan SMA, Direktorat Jenderal Pendidikan Dasar dan Menengah, n.d. 2018) the quality of education is a comprehensive picture and characteristic of goods or services that demonstrate its ability to satisfy expected needs that include inputs, processes, and educational outputs. Efficiency is defined as the comparison between output and input (Rizky Yudaruddin, 2017) Based on the Directorate of High School Development of the Ministry of Education and Culture (Direktorat Pembinaan SMA, Direktorat Jenderal Pendidikan Dasar dan Menengah, n.d.2018: 16 2018) especially related to the quality of school output, it is said to be quality when school performance in this case students show high achievement in academic achievement. Inputoutput research looks for ways educational inputs are converted into educational outcomes (Marini, 2012).

At this time, private high schools face a big challenge, namely with free schools. Where the data of Jambi City High School in 2021. Private high schools are much more numerous with a total of 33 schools, while public high schools only number 13 schools. The number of private high schools even makes parents reluctant to enroll their children in private high schools, due to several conditions such as the condition of facilities and infrastructure are alarming and the number of students is constantly decreasing each year. To know that the management of the school is managed appropriately or efficiently to be in demand by all parties, private high schools must make efficient. The only exception is private schools, which are positively related to efficiency and equality (Woessmann, 2011). Efficient in this case is in the use of school inputs to produce maximum school output. (Mulyati, 2013) in his literature studies suggests that the calculation of improvement of each school can help the relevant parties to determine the number of inputs and output targets used in achieving efficient conditions. School inputs in this study are students, study groups, teachers, administrative personnel, classrooms, and support rooms. The school output in this study was the number of graduates. So that if the management of school inputs is carried out to the maximum, then the output of the school produced is technically correct. Measurement of technical efficiency of schools using multi-input and multi-output is expected to provide a new nuance of school performance and can explain school performance in real time (Mulyadi JMV, 2016).

Research conducted by (Decker, 2014) the number of graduates at various levels is by far the most commonly used output variable included in the analysis of efficiency estimates. In 
addition, there is also research on the ratio of students per class, Indriati, (2014) determination of priority scale, identification and synchronization of data on physical facilities and infrastructure, whether held new procurement, new buildings, rehab or routine maintenance. The same is revealed (Mulyadi JMV, 2016: 21) factors that cause schools to be inefficient are the ratio of students to administrative personnel and the ratio of students to teachers. Based on the explanation above, it is necessary to conduct an assessment on the efficiency of school management, which is expected later with each input can explain the performance of the school in a rill and can help the school in achieving efficient school conditions.

This study aims to analyze factors or inputs that affect the number of graduates of private high schools in Jambi City and measure the level of technical efficiency of private high schools in Jambi City. The results showed that the factors or inputs that influenced the number of private high school graduates in Jambi city from 2015-2019 were students and classrooms.

\section{METHODS}

This research uses a quantitative approach. The research method used is descriptive method. The samples in this study amounted to 27 private high schools in Jambi City. The data source in the study came from the Ministry of Education and Culture from 2015-2019. This study uses panel data which is a combination of cross section data with periodic data (time series). (Mulyati, 2018) measures the efficiency of public high school education using data analysis envelopment analysis (DEA) and variable return to scale (VRS). (Togatorop, 2017) measures the cost of education against the quality of private high schools using track analysis. In addition, there is also about the ratio of perelas students, (Indriati, 2014) priority scale determination, identification and synchronization of data regarding physical facilities and infrastructure, whether new procurement, new buildings, rehab or routine maintenance. (Indriati, 2014) the number of graduates at various levels is by far the most commonly used output variable included in the efficiency estimation analysis.

The school's efficiency measurements are carried out using Stochastic Frontier Analysis (SFA). Stochastic Frontier Analysis (SFA) is one of the parametric approaches used for technical efficiency measurement. The advantage of this approach is that the hypothesis can be tested statistically and the relationship between input and output follows a known function (Putri, 2019). Output research assumes that school performance results are directly linked to inputs such as: expenses for each student, teacher characteristics, teacher-student ratio, and characteristics of students and their families, the result of which is a score from the test (A Marini, 2016).

\section{RESULTS AND DISCUSSION}

Analysis of the production function of SFA (Stochastic Frontier Analysis) used in testing the efficiency of the management of private high schools in Jambi City from 2015-2019 is a production function Cobb-Douglas conducted simultaneously using the software program Frontier Version 4.1C consisting of 6 variables of descriptors, namely: students, study groups, teachers, administrative personnel, classrooms, and support rooms. The results of the analysis are described in Table 1, the following: 
Tabel 1. Estimation of Parameters and $t$ Ratio of SFA Production Function Model (Stochastic Frontier Analysis)Using MLE

\begin{tabular}{lcrr}
\hline \multicolumn{1}{c}{ Variable } & Parameters & Coefficient & \multicolumn{1}{c}{ t-ratio } \\
\hline School Input & & & \\
Interception & $\beta_{0}$ & 3,77 & 0,47 \\
Students & $\beta_{1}$ & 0,23 & $5,22^{* * *}$ \\
Study Groups & $\beta_{2}$ & $-0,43$ & $-0,23$ \\
Teachers & $\beta_{3}$ & 0,04 & 0,09 \\
Administrative Personnel & $\beta_{4}$ & $-0,29$ & $-0,21$ \\
Classrooms & $\beta_{5}$ & 3,86 & $2,72^{* * *}$ \\
Support Rooms & $\beta_{6}$ & $-1,16$ & $-0,68$ \\
Variant Parameters & & & \\
Sigma-squared & & 662,38 & 1,96 \\
Gamma & & 0,41 & 1,24 \\
Log-Likelihood OLS & & $-601,06$ & \\
Log-Likelihood MLE & & $-600,11$ & \\
LR & & 1,90 & \\
Mean TE & & 0,49 & \\
ST & & & \\
\hline
\end{tabular}

Source: Primary data, 2021 (processed)

Information:

$* * *$ : real at $a=1 \% ; * *$ : real at $a=5 \% ; *$ : real at $=10 \%$

Table 1, shows that the signs and magnitude of parameters in the cobb-Douglas production function have been following the desired expectations. Positive signs indicate a direct relationship between school inputs and the number of graduates. Negative signs indicate a decrease in the number of graduates in line with the increase in variables. Based on the results of the estimated production function of Cobb-Douglas, two school inputs affect the number of graduates, namely: students, and classrooms. Students and classrooms have a very real effect on the $99 \%$ level of trust. Mathematically the Cobb-Douglas production function model is described in the following equation:

$$
\operatorname{Ln} Q=3,77+0,23 \operatorname{InPd}-0,43 \operatorname{InRb}+0,04 \operatorname{InG}-0,29 \operatorname{InTa}+3,86 \operatorname{InRk}-1,16 \operatorname{InRp}+\mathrm{v}_{\mathrm{i}}-\mathrm{u}_{\mathrm{i}}
$$

Based on the results of efficiency tests with frontier version 4.1C software program, the technical efficiency level of private high schools in Jambi City from 2015-2019 is described in Table 2, the following: 
Table 2. Technical Efficiency Levels of Private High Schools in Jambi City from 2015-2019

\begin{tabular}{|c|c|c|c|c|c|c|}
\hline \multirow{2}{*}{ No. } & \multirow{2}{*}{ School Name } & \multicolumn{5}{|c|}{ Technical Efficiency Level } \\
\hline & & 2015 & 2016 & 2017 & 2018 & 2019 \\
\hline 1 & Xaverius Private High School 2 Jambi & 1 & 1 & 1 & 1 & 1 \\
\hline 2 & Private High SchoolNusantara Jambi & 1 & 1 & 1 & 1 & 1 \\
\hline 3 & AttaufiqPrivate High School & 1 & 1 & 1 & 1 & 1 \\
\hline 4 & Jambi IX LurahPrivate High School & 1 & 1 & 1 & 1 & 1 \\
\hline 5 & Private High SchoolSuryalbu & 1 & 1 & 1 & 1 & 0,88 \\
\hline 6 & Al-Falah Islamic Private High School & 1 & 1 & 1 & 1 & 0,21 \\
\hline 7 & Private High SchoolUnggulSakti & 1 & 1 & 1 & 1 & 0,2 \\
\hline 8 & XaveriusPrivate High School 1 Jambi & 1 & 1 & 1 & 0,92 & 0,16 \\
\hline 9 & Ferdy Ferry PutraPrivate High School & 1 & 1 & 1 & 0,51 & 0,17 \\
\hline 10 & PGRIPrivate High School 2 Jambi & 1 & 1 & 1 & 0,15 & 0,15 \\
\hline 11 & PurnamaPrivate High School 2 Jambi & 1 & 1 & 1 & 0,12 & 0,16 \\
\hline 12 & Sariputra National Private High School & 1 & 1 & 0,79 & 0,14 & 0,15 \\
\hline 13 & MuhammadiyahPrivate High School & 1 & 1 & 0,42 & 0,13 & 0,14 \\
\hline 14 & MegatamaPrivate High School & 1 & 1 & 0,11 & 0,11 & 0,12 \\
\hline 15 & Private High SchoolDua Mei Jambi & 1 & 0,1 & 0,08 & 0,09 & 0,09 \\
\hline 16 & Dharma BhaktiPrivate High School3 & 1 & 0,07 & 0,08 & 0,08 & 0,09 \\
\hline 17 & YadikaPrivate High School & 1 & 0,07 & 0,08 & 0,08 & 0,09 \\
\hline 18 & NomensenPrivate High School & 0,98 & 0,07 & 0,08 & 0,08 & 0,09 \\
\hline 19 & Dharma BhaktiPrivate High School 4 & 0,76 & 0,07 & 0,07 & 0,08 & 0,08 \\
\hline 20 & Dharma BhaktiPrivate High School 2 & 0,69 & 0,07 & 0,07 & 0,08 & 0,08 \\
\hline 21 & $\begin{array}{l}\text { Al-Azhar Integrated Islamic Private } \\
\text { High School Jambi City }\end{array}$ & 0,67 & 0,06 & 0,07 & 0,08 & 0,08 \\
\hline 22 & Pelita RayaPrivate High School & 0,48 & 0,07 & 0,07 & 0,08 & 0,08 \\
\hline 23 & AdhyaksaPrivate High School 1 Jambi & 0,43 & 0,07 & 0,07 & 0,08 & 0,08 \\
\hline 24 & PGRIPrivate High School 3 Jambi & 0,11 & 0,06 & 0,06 & 0,07 & 0,07 \\
\hline 25 & $\begin{array}{l}\text { Private Christian High School Bina } \\
\text { Kasih }\end{array}$ & 0,03 & 0,03 & 0,03 & 0,03 & 0,03 \\
\hline 26 & YPWIPrivate High School & 0,005 & 0,005 & 0,01 & 0,01 & 0,01 \\
\hline \multirow[t]{2}{*}{27} & PertiwiPrivate High School & 0,003 & 0,003 & 0,003 & 0,003 & 0,004 \\
\hline & Average & 0,78 & 0,55 & 0,48 & 0,37 & 0,27 \\
\hline
\end{tabular}

Source: Primary data, 2021 (processed)

In Table 3, the level of technical efficiency of private high schools in Jambi city from 2015-2019, the highest in 2015 reached 0,78, in 2016 reached 0,55, in 2017 only reached 0,48 and 0,37 occurred in 2018 and the lowest number occurred in 2019 only 0,27. From 27 private high schools in Jambi City from 2015-2019 obtained 4 efficient (14,81 percent), namely: XaveriusPrivate High School 2 Jambi, Private High SchoolNusantara Jambi, Attaufiq Private High School, and Jambi IX Lurah Private High School. While from 2015-2019 there were 23 private high schools $(85,19$ percent) that were inefficient, namely: Private High School Surya Ibu, Al-Falah Islamic Private High School, Private High School UnggulSakti, Xaverius Private High School 1 Jambi, Ferdy Ferry Putra Private High School, PGRI Private High School 2 Jambi, Purnama Private High School 2 Jambi, Sariputra National Private High School, 
Muhammadiyah Private High School, Megatama Private High School, Private High School Dua Mei Jambi, Dharma Bhakti Private High School 3, Yadika Private High School, Nomensen Private High School, Dharma Bhakti Private High School 4, Dharma Bhakti Private High School 2, Al-Azhar Integrated Islamic Private High School Jambi City, Pelita Raya Private High School, Adhyaksa Private High School 1 Jambi, PGRI Private High School 3 Jambi, Private Christian High School BinaKasih, YPWI Private High School and Pertiwi Private High School.

\section{DISCUSSION}

Cobb Douglass parameter testing is done in two stages. The first stage uses the ordinary least square(OLS) method and the second stage uses the maximum likelihood estimation(MLE) method. In Table 2, the log-likelihood value by using the MLE method $(-600,11)$ is greater than the log-likelihood value by using the OLS method $(-601,06)$, thus the production function by the MLE method is good and appropriate field conditions. The gamma value $(0,41)$ is interpreted that all term errors are a result of a random model (Vi) error, hence the inefficiency coefficient parameter becomes meaningless. The ratio generalizalized-likelihood (LR-test) is $(1,90)$.

According to (Kuswanto, 2019) conducted a study through his research on the impact of rubber production efficiency on the welfare of farmers in Jambi Province analyzed using the approach of the stochastic frontier production function the results showed that the value of loglikelihood with MLE method $(-29,39)$ is greater than the value of log-likelihood with OLS method $(-38,47)$, thus the production function with MLE method is better and following the conditions in the field. (Kuswanto, 2019) conducted a study through his research on analysis efficiency of learning students Bidikmisi analyzed using the approach of the stochastic production function frontier results showed that the value of log-likelihood with the MLE method $(85,52)$ is greater than the value of log-likelihood with OLS method $(55,52)$, thus the production function with MLE method is better and following the conditions in the field.

Based on the results of the analysis as shown in Table 2, the student's variable coefficient value $(0,23)$ was obtained and had a very real effect on the level of trust of 99 percent of the number of graduates. This explains that increasing the number of students will increase the number of graduates by 0,23 percent. Based on the Directorate General of Teachers and Educational Personnel of the Ministry of Education and Culture (Morphology, n.d. 2019: 8) the purpose of student management is to organize student activities so that all activities can lead to the achievement of competencies for each level and type of school. The student component is indispensable in school because the learner is both a subject and an object in the learning process (Perdana, 2018: 2). Previous research relevant to these results is as conducted by (Umi et al., 2020), that student management can be used to help the development and growth of students optimally through the educational process in schools.

Based on the results of the analysis as shown in Table 2, the study group statistically had no real effect on both the 90 percent and 95 percent confidence levels. The coefficient value indicates a negative value, indicative of this condition is the role of the study group is not ideal to increase the number of graduates. To achieve a quality school, the learning process must be effective, one way to achieve this is by arranging the number of students in the study group (Perdana, 2018). Research conducted by (Islakhudin, 2020) in the results of his research suggests that the number of students in a study group is very influential on the learning process. Similarly, the research conducted by (Perdana, 2018), that at the high school level on the island of Sumatra, among the ten provinces that have an average ratio of high school students above the ratio of national students ramble is the provinces of North Sumatra, South Sumatra, and Lampung. 
Based on the results of the analysis as shown in Table 2, the role of teachers statistically has no real effect on both the 95 percent and 90 percent confidence levels. Although the coefficient shows a positive value, the increase does not represent an increase in the number of graduates each year. Previous research relevant to this result is as done by (Susanti \& Sa'ud, 2016), that after training many teachers have not been able to apply the results of professional development into real practice. While the research conducted by (Herawati, 2018) that professional teacher management in the future requires a change in strategy so that the Provincial Government can carry out its duties as needed. Indriati, (2014) in his research results suggested that to improve efficiency in the field of education, schools are allowed to appoint Teachers Not Permanent (TNP) who are paid with school operational funds.

Based on the results of the analysis as shown in Table 2, the role of administrative personnel statistically has no real effect on both the level of trust of 95 percent and 90 percent. The coefficient value indicates a negative value, indications of this condition is the role of administrative personnel has not been ideal to increase the number of graduates. Currently, employees who serve administrative jobs or educational personnel do not have provisions that can be used as a basis for the requirements of the number of educational personnel (Helianty, 2014: 251). Previous research relevant to these results is as done by (Dr. Mulyadi JMV, 2016) that the variable ratio of student-administrative employees negatively affects school performance. Similarly, the research conducted by (Bafadal, 2018), that the projected data of administrative personnel of high schools and vocational schools in Ngawi District in the last ten years was reviewed from the ratio of students experiencing shortages. While the research conducted by (Bachtiyar, 2017), that the needs of school administration personnel in each school has a certain amount of accumulation in each year.

Based on the results of the analysis as shown in Table 2, a classrooms variable coefficient value of $(3,86)$ was obtained and had a very real effect on the level of trust of 99 percent of the number of graduates. This explains that a 1 percent increase in the number of classrooms will increase the number of graduates by 3.86 percent. Classroom management is an activity to create and maintain optimal conditions in the learning process (Rosidah, 2018: 211). Previous research relevant to this result is as done by (Hajeriani, 2019) that class management positively affects learning outcomes. Similarly, research conducted by (Arumsari, 2017), that classroom management skills have a significant influence on learning achievements. The results of research conducted by (Yuliani \& Sucihatiningsih, 2014), that class management directly affects the results of learning.

Based on the results of the analysis as shown in Table 2, the value of the support rooms variable coefficient $(-1,16)$ and statistically has no real effect on both the 90 percent and 95 percent confidence levels. This explains that the more support rooms in this case the library room and laboratory room in one school will reduce the level of the number of graduates. Support rooms management in the world of education is important in supporting the learning process in schools (Perdana, 2018). Previous research relevant to this result is as conducted by Yuliani \& Sucihatiningsih, (2014), that learning facilities have an indirect effect on learning outcomes. While the research conducted by (Anas, 2016) that input in education does not have to be learners but includes infrastructure facilities that can be used for education. Similarly, research conducted by Indriati, (2014) determined priority scale, identification, and synchronization of data on physical facilities and infrastructure, whether held new procurement, new buildings, rehab, or routine maintenance. 


\section{CONCLUSION}

Based on the results of the analysis of the efficiency of the management of private high schools in Jambi City from 2015-2019 using the Stochastic Frontier Analysis (SFA) method, it can be concluded that: factors or inputs that affect the number of graduates of private high schools in Jambi City from 2015-2019 are students and classrooms. While the factors or inputs that do not affect the number of graduates are study groups, teachers, administrative personnel and support rooms. (Mulyati, 2018) conducted a study through his research on the efficiency analysis of public high school education in Semarang Regency analyzed using data envelopment analysis (DEA) methods the results showed that the factors that affect input quality are the ratio of students per teacher, the ratio of students per administrative employee, and the influence of quality of output is the percentage of graduation. The technical efficiency level of 27 private high schools in Jambi City from 2015-2019, the highest in 2015 reached $0,78=78 \%$, the lowest figure occurred in 2019 with $0,27=27 \%$, and the average only reached $0,49=49 \%$. This explains that the efficiency of managing private high schools in Jambi city has not been efficient. (Isa, 2011) conducted a study through his research on the technical efficiency of education in surakarta city analyzed using data envelopment analysis (DEA) methods the results showed that 70.73 percent of high schools in Surakarta were efficient and another 29.27 percent inefficient.

Efforts that must be made so that private high schools in Jambi City are technically efficient by combining factors or inputs in accordance with Government Regulation of the Republic of Indonesia Number 19 of 2005 on National Standards of Education in article 2 paragraph 1 mentioned that the scope of national standards of education includes: graduate competency standards, facilities and infrastructure standards, namely (1) optimizing the achievement of graduate competence consisting of qualification criteria for participants' abilities. Students who are expected to be achieved after completing their study period in the secondary education unit, (2) the addition of classrooms is needed to create a comfortable and disciplined learning atmosphere, orderly, anti-smoking and drug, harmony between teachers, students and parents and maintain optimal conditions in the learning process. 


\section{REFERENCES}

Anas, M. (2016). 2. Anas Publised 2016 vol 2. 1(2), 47-58.

Arumsari, D. (2017). Pengaruh Media Pembelajaran Dan Keterampilan Pengelolaan Kelas Terhadap Prestasi Belajar Siswa SMK Negeri 5 Madiun. Assets: Jurnal Akuntansi Dan Pendidikan, 6(1), 13. https://doi.org/10.25273/jap.v6i1.1290

Bachtiyar, Y. (2017). Analisis Kebutuhan Tenaga Administrasi Sekolah ( Tas ). Jurnal Manajemen Dan Supervisi Pendidikan, 1(3), 196-200.

Bafadal, I. (2018). Analisis kebutuhan tenaga administrasi sekolah pada jenjang sma dan smk. 1, 388-399.

Decker, B. R. (2014). Estimating the Efficiency of Four-year Public Master's Universities in Arkansas Using Data Envelopment Analysis. Dissertation Abstracts International, A: The Humanities and Social Sciences, 76(01).

Direktorat Pembinaan SMA, Direktorat Jenderal Pendidikan Dasar dan Menengah, K. P. dan K. (n.d.). Manajemen Berbasis Sekolah (MBS) SMA.

Dr. Mulyadi JMV. (2016). Aplikasi Data Envelopment Analysis. 13, 83.

Hajeriani, S. (2019). Phinisi Integration Review Pengaruh Pengelolaan Kelas , Pemanfaatan Sarana Dan Prasarana Se-Kecamatan Belawa Kabupaten Wajo. 2(1).

Helianty, Y. (2014). Analisis Kebutuhan Jumlah Pegawai Berdasarkan Analisis Beban Kerja. Jurnal Reka Integra, 01(04), 250-258.

Herawati, N. R. (2018). Analisis Politik Alih Kewenangan Pengelolaan Guru Sma/Smk Dari Pemerintah Kabupaten/Kota Kepada Pemerintah Provinsi. Jurnal Ilmu Sosial, 16(2), 72. https://doi.org/10.14710/jis.16.2.2017.72-93

Indriati, N. E. (2014). Analisis Efisiensi Belanja Daerah di Kabupaten Sumbawa (Studi Kasus Bidang Pendidikan dan Kesehatan). Jesp, 6(2), 192-205.

Isa. (2011). Efisiensi Teknis Pendidikan di Kota Surakarta: Aplikasi Data Envelopment Analysis (DEA). Jurnal Manajemen Dan Bisnis, 3(2), 14-22.

https://doi.org/http://journals.ums.ac.id/index.php/benefit/article/view/1303

Islakhudin, M. (2020). Pengaruh Rombongan Belajar Siswa Terhadap Perkembangan Kognitif Sosial Peserta Didik Di Mi Ma ’Arif Ngampeldento Salaman. 8, 139-158.

Kuswanto, K. (2019). The Analysis of the Learning Efficiency of Bidikmisi Students. Jurnal Pendidikan Ekonomi Dan Bisnis (JPEB), 7(1), 10-21. https://doi.org/10.21009/jpeb.007.1.2

Kuswanto Kuswanto, Zulkifli Alamsyah, Armandelis Armandelis, Z. Z. (2019). The Impact of the Efficiency of Rubber Production on the Welfare of Rubber Farmers in Jambi Province. International Journal of Economics and Financial Issues, 9(2), 80-86. https://doi.org/10.32479/ijefi.7503

Marini, A. (2016). Manajemen Pendidikan Teori dan Aplikasinya. Ombak.

Marini, Arita. (2010). Teori dan Aplikasinya. Jakarta: Rineka Cipta.

Menteri Pendidikan dan Keb. (2017). Salinan Menteri Pendidikan Dan Kebudayaan Republik Indonesia Peraturan Menteri Pendidikan Dan Kebudayaan Republik Indonesia Nomor 17 Tahun 2017 Tentang Penerimaan Peserta Didik Baru Pada Taman Kanak-Kanak, 
Sekolah Dasar, Sekolah Menengah Pertama, Sekolah . Kementerian Pendidikan Dan Kebudayaan, 1(1), 1-20.

Morphology, T. C. (n.d.). Modul Pelatihan Penguatan Kepala Sekolah Pengelolaan Peserta Didik (MPPKS - DIK).

Mulyati. (2018). Analisis Efisiensi Pendidikan Sekolah Menengah Atas Negeri (SMAN) di Kabupaten Semarang. Economics Development Analysis Journal, 7(2). https://doi.org/https://doi.org/10.15294/edaj.v7i1.21936.

Mulyati, S. (2013). Economics Development Analysis Journal. 2(4), 446-455.

Perdana, N. S. (2018). Analisis Capaian Rombongan Belajar Di Provinsi Lampung Tahun 2018 Dalam Upaya Implementasi Permendikbud Nomor 17 Tahun 2017. Dewantara, V, $1-16$.

Putri, T. A., Kusnadi, N., dan Rachmina, D. (2019). Efisiensi Teknis Usaha Penggilingan Padi di Kabupaten Cianjur: Pendekatan Stochastic Frontier Analysis. Jurnal AGRISEP, 18(2), 203-218.

https://doi.org/https://ejournal.unib.ac.id/index.php/agrisep/article/view/7419

Rizky Yudaruddin. (2017). JURNAL AKUNTANSI \& EKONOMI FE. UN PGRI Kediri Vol. 2 No. 1, Maret 2017. 2(1), 1-11.

Rosidah, R. (2018). Strategi Pengelolaan Kelas Efektif dan Efisien Dalam Proses Pembelajaran. Jurnal Teknologi Pendidikan Madrasah, 1(2), 208-217. https://doi.org/10.5281/zenodo.1421013

Soedibyo. (2003). Undang-Undang Republik Indonesia Nomor 20 Tahun 2003 Tentang Sistem Pendidikan Nasional. Teknik Bendungan, 1.

Susanti, A., \& Indonesia, U. P. (2016). EFEKTIFITAS PENGELOLAAN PENGEMBANGAN. 2, 37-51.

Togatorop, M. (2017). Pengaruh Biaya Pendidikan Terhadap Mutu Sekolah SMA Swasta. Jurnal Pendidikan Dan Kebudayaan, 7(3). https://doi.org/https://garuda.ristekbrin.go.id/documents/detail/623273

Umi, F., Marsidin, S., \& Sabandi, A. (2020). Analisis Kebijakan dan Pengelolaan terkait Peserta Didik di Sekolah Dasar. Edukatif: Jurnal Ilmu Pendidikan, 2(2), 128-133. https://doi.org/10.31004/edukatif.v2i2.114

Woessmann, L. (2010). Institutional determinants of school efficiency and equity: German states as a microcosm for OECD countries. Jahrbucher Fur Nationalokonomie Und Statistik, 230(2), 234-270. https://doi.org/10.1515/jbnst-2010-0206

Yuliani, P., \& Sucihatiningsih, D. W. P. (2014). Pengaruh Fasilitas Belajar, Pengelolaan Kelas, Dan Lingkungan Keluarga Terhadap Hasil Belajar Ekonomi Melalui Motivasi Belajar Siswa Kelas Xi Ma Al-Asror Kota Semarang. Economic Education Analysis Journal, 3(1), 24-30. 